agriTECH, 41 (1) 2021, 15-24

\title{
Karakterisasi Fisikokimia Beras Hitam (Oryza sativa L.) dari Jawa Barat, Indonesia
}

\author{
Physicochemical Properties of Black Rice (Oryza sativa L.) from West Jawa, Indonesia \\ Amalia Hana Arifa, Elvira Syamsir*, Slamet Budijanto \\ Departemen Ilmu dan Teknologi Pangan, Fakultas Teknologi Pertanian, Institut Pertanian Bogor, \\ Jl. Raya Dramaga, Babakan Kec. Dramaga, Bogor, Jawa Barat 16680 Indonesia \\ *Penulis korespondensi: Elvira Syamsir, Email: elvira_itp@ipb.ac.id
}

Tanggal submisi: 9 Januari 2020; Tanggal revisi: 22 April 2020, 6 Mei 2020; Tanggal penerimaan: 7 Mei 2020

\begin{abstract}
ABSTRAK
Beras berpigmen seperti beras hitam mengandung senyawa bioaktif yang berpotensi sebagai sumber pangan fungsional. Dalam hal pemanfaatan beras hitam sebagai sumber pangan fungsional, perlu diketahui karakteristiknya agar dapat diketahui metode pengolahan dan jenis produk yang sesuai dengan karakteristiknya. Penelitian ini bertujuan mengetahui karakteristik fisikokimia empat varietas beras hitam yang berasal dari Jawa Barat, yaitu Cempo Ireng yang berasal dari Bogor, Galur dan Gadog dari Subang, serta beras hitam Cianjur. Parameter yang diuji adalah total senyawa fenolik, antosianin, pati, amilosa serta amilopektin, profil pasting, solubility, dan swelling power. Hasil penelitian menunjukkan bahwa masing-masing beras hitam memiliki karakteristik fisikokimia yang berbeda-beda. Beras hitam yang diuji memiliki karakteristik sebagai berikut: kadar total senyawa fenolik 261,7 $353,0 \mathrm{mg}$ GAE$/ 100 \mathrm{~g}$ bk, antosianin $52,4-126,1 \mathrm{mg} / 100 \mathrm{~g}$ bk, pati $69,8-72,8 \%$ bk, amilosa $22,4-26,1 \%$ bk, sedangkan kadar amilopektinnya $45,3-48,7 \%$ bk. Beras hitam yang diuji juga memiliki nilai solubility $6,4-8,4 \%$ dan swelling power 6,3 - 7,3\%. Beras Cempo Ireng memiliki viskositas puncak dan viskositas breakdown tertinggi. Beras Cianjur dan Cempo Ireng memiliki viskositas akhir tertinggi. Beras Galur memiliki viskositas setback tertinggi. Beras Cianjur juga memiliki suhu pasting dan peak time yang paling tinggi dibandingkan dengan sampel lainnya.
\end{abstract}

Kata kunci: Beras hitam; pangan fungsional; karakteristik fisikokimia

\begin{abstract}
Pigmented rice, such as black rice, has bioactive compounds that made black rice a potential source of functional food. However, to investigate black rice as a source of functional food, it is necessary to characterize its physicochemical properties. Therefore proper processing methods and potential end products can be determined according to their properties. This study aims to analyze the physicochemical characteristics of four Black Rice varieties from several districts in West Java, namely Cempo Ireng from Bogor, Galur and Gadog from Subang, and Cianjur black rice. In addition, the physicochemical characteristics of black rice that were analyzed consist of total phenolic, anthocyanin, starch, amylose, and amylopectin content, pasting characteristics, solubility, and swelling power. The results showed that each black rice varieties had different physicochemical characteristics. Furthermore, the total phenolic content of black rice ranged from $261,7-353,0 \mathrm{mg} \mathrm{GAE} / 100 \mathrm{~g} \mathrm{db}$, anthocyanin content ranged from $52,4-126,1 \mathrm{mg} / 100 \mathrm{~g} \mathrm{db}$, total starch content ranged from $69,8-72,8 \% \mathrm{db}$, amylose content ranged from $22,4-26,1 \% \mathrm{db}$. Meanwhile, the amylopectin content ranged from $45,3-48,7 \% \mathrm{db}$. Solubility value ranged from $6,4-8,4 \%$ and swelling power value ranged from $6,3-7,3 \%$. Cempo Ireng had the
\end{abstract}


highest peak and breakdown viscosity. Meanwhile, Cianjur and Cempo Ireng variety had the highest final viscosity. Galur variety had the highest setback viscosity. On the other hand, Cianjur black rice variety also had the highest pasting temperature and peak time when compared to other black rice varieties.

Keywords: Black rice; functional food; physicochemical characteristics

\section{PENDAHULUAN}

Beras hitam (Oryza sativa L.) merupakan beras berpigmen yang memiliki bekatul berwarna hitam yang menutupi bagian endospermanya (Kang dkk., 2011). Konsumsi beras berpigmen seperti beras hitam saat ini mulai meningkat karena masyarakat sudah mulai mengubah pola konsumsi pangannya ke arah pangan yang bermanfaat untuk kesehatan, yaitu pangan fungsional. Beras hitam berpotensi sebagai pangan fungsional karena memiliki kandungan komponen bioaktif, yaitu senyawa polifenol, flavonoid, asam fitat, dan $\gamma$-orizanol yang berperan sebagai antioksidan, anti inflamasi dan memiliki manfaat penting lainnya untuk kesehatan (Kong dkk., 2012; Pang dkk., 2018). Keunggulan lainnya yang dimiliki oleh beras hitam adalah pada kandungan mineral; senyawa fitokimia seperti asam lemak tidak jenuh, GABA, y-orizanol, protein, fenolik, antosianin, dan vitamin; yang komposisinya tergantung pada kultivar dan lokasi penanamannya (Kushwaha, 2016; Pengkumsri dkk., 2015; Sompong dkk., 2011).

Beras hitam merupakan salah satu jenis beras berpigmen yang populer di negara-negara Asia. Menurut Pengkumsri dkk. (2015), Cina merupakan negara penghasil beras hitam tertinggi di Asia, yang diikuti oleh Sri Lanka, Indonesia, India, Filipina, serta Thailand yang berada pada urutan ke-9. Petani di beberapa daerah di Indonesia juga sudah mulai banyak yang membudidayakan beras hitam, seperti di daerah Yogyakarta, Sulawesi, dan Jawa Barat. Beras pada umumnya dikonsumsi dalam bentuk nasi, namun saat ini bentuk pemanfaatan beras sebagai produk pangan sudah mulai banyak berkembang. Beras juga dapat diolah dalam bentuk tepung, yang selanjutnya dapat digunakan sebagai bahan baku pembuatan bihun, kue maupun produk pangan lainnya sebagai bentuk diversifikasi pangan.

Menurut Nurhidajah dkk. (2018), saat ini penyakit kardiovaskular merupakan salah satu penyebab utama kematian di Indonesia, sehingga diperlukan pola konsumsi pangan yang sehat. Konsumsi produk pangan fungsional seperti beras hitam dapat dijadikan sebagai salah satu alternatif untuk menurunkan resiko timbulnya penyakit degeneratif karena keunggulan kandungan senyawa bioaktif yang dimiliki oleh beras hitam. Oleh sebab itu, penelitian mengenai pemanfaatan beras hitam sebagai produk pangan fungsional perlu dilakukan sebagai upaya untuk menurunkan resiko timbulnya penyakit degeneratif akibat pola konsumsi pangan yang tidak sehat dan juga sebagai salah satu bentuk dukungan terhadap program diversifikasi pangan.

Sebagai upaya pemanfaatan beras hitam untuk pengolahan produk pangan fungsional, maka diperlukan informasi mengenai karakteristik fisikokimia dari beras hitam itu sendiri agar dapat diketahui bagaimana potensi pengembangan produk yang sesuai dengan karakteristik yang dimiliki. Penelitian mengenai karakteristik beras hitam yang berasal dari Cina dan Thailand telah dilakukan oleh Sompong dkk. (2011), yang meliputi karakteristik kimiawi (total fenolik, antosianin, amilosa dan kapasitas antioksidan) serta karakteristik fisik (profil pasting). Penelitian mengenai karakteristik beras hitam yang berasal dari Indonesia telah dilakukan oleh Nurhidajah dkk. (2018), dengan menggunakan beras hitam varietas lokal yang berasal dari Bantul untuk melihat karakteristik kimianya (proksimat, kadar amilosa, amilopektin, serat tidak larut, serat larut, dan serat pangan total) akibat variasi metode pengolahan, namun pada penelitian tersebut belum dilakukan analisis komponen bioaktif seperti senyawa fenolik dan karakteristik fisiknya. Penelitian mengenai karakteristik fisikokimia beras hitam yang berasal dari daerah Jawa Barat juga belum banyak dilakukan. Oleh sebab itu, pada penelitian ini selain dilakukan analisis sifat kimia (kadar total fenolik, antosianin, pati, dan amilosa-amilopektin), juga dilakukan analisis sifat fisik (profil pasting, solubility, dan swelling power) terhadap beberapa varietas beras hitam yang berasal dari daerah Jawa Barat, sehingga dapat diketahui potensi pengembangannya sebagai produk pangan fungsional. Selain itu, hasil yang diperoleh dari penelitian ini diharapkan dapat berkontribusi dalam pengembangan keilmuan, yaitu dengan berkembangnya penelitianpenelitian lanjutan yang menggali potensi beras hitam di Indonesia.

\section{METODE PENELITIAN}

\section{Bahan}

Bahan utama yang digunakan pada penelitian ini adalah 4 varietas beras hitam pecah kulit, yaitu Cempo Ireng yang berasal dari Kecamatan Cigudeg, Kabupaten Bogor; Galur dan Gadog yang berasal dari Desa 
Cibeusi, Kecamatan Ciater, Subang; dan beras hitam Cianjur yang berasal dari Desa Sukasirna, Kecamatan Campakamulya, Kabupaten Cianjur. Bahan-bahan yang digunakan untuk analisis kimia di antaranya adalah akuades, reagen Folin-Ciocalteu, standar asam galat, $\mathrm{Na}_{2} \mathrm{CO}_{3}$, etanol absolut, $\mathrm{HCl}$ pekat, $\mathrm{KCl}$, Na-asetat, dietil eter, $\mathrm{NaOH}$, reagen DNS, Na-K-tartrat, standar glukosa, standar amilosa, asam asetat, iodin, dan KI yang diperoleh dari Merck (Darmstad, Jerman).

\section{Alat}

Alat utama yang digunakan untuk preparasi sampel beras di antaranya adalah disc mill dan vibrating sieve 100 mesh (Tokuju Kosakusho Co., Ltd, Tokyo, Jepang). Alat-alat yang digunakan untuk analisis di antaranya adalah oven (Termaks, Bergen, Norwegia), spektrofotometer UV-VIS Genesys 150 (Thermo Fisher Scientific Inc., Waltham MA, USA), Rapid Visco Analyzer (RVA) Tec-Master (Newport Scientific, Warriewood, Australia), refrigerated centrifuge $5810 \mathrm{R}$ (Eppendorf AG, Jerman), waterbath shaker 1083 (GFL/Gesellschaft für Labortechbik mbH D-30938 Burgwedel, Jerman), dan peralatan gelas.

\section{Preparasi Sampel Beras Hitam}

Sampel beras yang akan dianalisis dijadikan tepung terlebih dahulu. Prosedur penepungan yang dilakukan adalah menggunakan metode penggilingan kering (Wu dkk., 2015). Beras hitam disortasi terlebih dahulu untuk membuang bagian-bagian yang tidak diinginkan seperti kotoran, batu, dan lain-lain. Beras yang sudah disortasi selanjutnya digiling menggunakan disc mill, kemudian diayak dengan menggunakan vibrating sieve 100 mesh. Tepung beras hitam selanjutnya disimpan dalam plastik polietilen untuk analisis selanjutnya.

\section{Analisis Total Senyawa Fenolik}

Analisis total senyawa fenolik tepung beras hitam dilakukan dengan menggunakan metode FolinCiocalteau yang mengacu pada Widyasaputra (2018) dengan modifikasi. Sampel tepung beras diekstraksi terlebih dahulu dengan menggunakan etanol $70 \%$, dengan perbandingan sampel dan pelarut sebesar 1:20 (b/v). Ekstraksi dilakukan dengan menggunakan waterbath shaker pada suhu $55^{\circ} \mathrm{C}$ selama 3,5 jam. Kemudian sampel disentrifugasi selama 10 menit pada kecepatan $3000 \mathrm{rpm}$. Supernatan yang diperoleh dipisahkan untuk analisis lebih lanjut. Larutan standar untuk analisis dibuat dengan menggunakan asam galat. Sebanyak $400 \mu \mathrm{L}$ ekstrak sampel dan larutan standar ditambahkan dengan $200 \mu \mathrm{L}$ reagen Folin-Ciocalteu $50 \%$, kemudian didiamkan selama 5 menit. Selanjutnya dilakukan penambahan larutan $\mathrm{Na}_{2} \mathrm{CO}_{3} 2 \%$ sebanyak 4
$\mathrm{mL}$ dan diinkubasi selama 30 menit dalam kondisi gelap. Pengukuran total fenol dilakukan dengan menggunakan spektrofotometer UV-Vis pada panjang gelombang 750 $\mathrm{nm}$.

\section{Analisis Kadar Antosianin}

Analisis kadar antosianin dilakukan dengan menggunakan metode pH-diferensial yang mengacu pada Kang dkk. (2014) dengan modifikasi. Ekstraksi sampel dilakukan menggunakan etanol $70 \%$ yang diasamkan dengan $\mathrm{HCl} 1 \mathrm{~N}(85: 15$ (v/v)). Perbandingan antara sampel dan pelarut yang digunakan saat ekstraksi adalah 1:30 (b/v). Ekstraksi dilakukan dalam waterbath shaker selama 2 jam pada suhu $35^{\circ} \mathrm{C}$. Sampel disentrifugasi selama 20 menit pada suhu 4 ${ }^{\circ} \mathrm{C}$, kemudian supernatan dipisahkan untuk analisis selanjutnya.

Ekstrak sampel sebanyak 0,5 $\mathrm{mL}$ dimasukkan ke dalam 2 tabung reaksi, tabung pertama diisi dengan 4,5 mL larutan buffer $\mathrm{KCl} 0,025 \mathrm{M} \mathrm{pH} \mathrm{1,} \mathrm{sedangkan}$ tabung kedua diisi dengan $4,5 \mathrm{~mL}$ larutan buffer $\mathrm{Na}$ asetat $0,4 \mathrm{M} \mathrm{pH}$ 4,5. Sampel diinkubasi selama 15 menit pada ruangan gelap. Pengukuran total antosianin dilakukan dengan mengukur absorbansi sampel dengan spektrofotometer UV-Vis pada panjang gelombang 510 $\mathrm{nm}$ dan $700 \mathrm{~nm}$. Kadar antosianin diperoleh dari selisih absorbansi sampel yang diperoleh pada masing-masing $\mathrm{pH}$ larutan dan panjang gelombang. Kadar antosianin dihitung sebagai sianidin-3-glukosida dan dihitung dengan menggunaan Persamaan 1.

Konsentrasi antosianin

$(\mathrm{mg} / 100 \mathrm{~g}$ sampel $)=\frac{\mathrm{A} \times \mathrm{MW} \times \mathrm{DF} \times \mathrm{V} \times 100}{\varepsilon \times 1 \times \mathrm{W}}$

A adalah absorbansi sampel $=\left(A_{510^{-}} A_{700}\right)_{\mathrm{pH} \mathrm{1,0}}{ }^{-}\left(A_{510^{-}}\right.$ $\left.\mathrm{A}_{700}\right)_{\mathrm{pH} \mathrm{4,5}}$, MW adalah berat molekul dihitung sebagai sianidin-3-glukosida ( $M W=449,2)$, DF adalah faktor pengenceran, $\mathrm{V}$ adalah volume larutan induk sampel, W adalah berat sampel $(\mathrm{g})$, dan $\mathrm{E}$ adalah adsorptivitas molar sianidin-3-glukosida $(\varepsilon=26,900)$.

\section{Analisis Kadar Pati}

Analisis kadar pati dilakukan dengan menggunakan metode DNS yang mengacu pada Sani dkk. (2014) dengan modifikasi. Sampel sebanyak 0,1 g dicuci dengan $5 \mathrm{~mL}$ dietil eter untuk menghilangkan komponen lemak, dibiarkan hingga pelarutnya menguap. Sampel selanjutnya dicuci sebanyak 2 kali menggunakan $4 \mathrm{~mL}$ etanol $80 \%$, kemudian dipanaskan dalam waterbath untuk menguapkan sisa-sisa etanol. Selanjutnya dilakukan hidrolisis sampel menggunakan $\mathrm{HCl} 7 \%$ selama 2,5 jam dalam waterbath. Sampel yang telah 
dihidrolisis selanjutnya ditambahkan $\mathrm{NaOH} 25 \%$ untuk menetralkan $\mathrm{pH}$ (hingga $\mathrm{pH} 7 \pm 0,1$ ), kemudian disaring dan ditepatkan volumenya hingga $100 \mathrm{~mL}$ dengan akuades untuk selanjutnya dilakukan analisis. Masingmasing larutan standar glukosa dan sampel sebanyak $0,5 \mathrm{~mL}$ ditambahkan dengan akuades $1,5 \mathrm{~mL}$ dan reagen DNS sebanyak $3 \mathrm{~mL}$, kemudian dipanaskan selama 10 menit dan didinginkan. Larutan sampel dan standar selanjutnya dibaca absorbansinya menggunakan spektrofotometer UV-Vis pada panjang gelombang 540 $\mathrm{nm}$. Kadar pati sampel diperoleh dengan menggunakan Persamaan 3.

Gula reduksi $=\frac{\mathrm{C} \times \mathrm{FP} \times \text { volume filtrat }}{\text { berat sampel }}$

Kadar pati $(\%)=$ gula reduksi $\times 0,9 \times 100$

C adalah konsentrasi pati sampel dari kurva standar, 0,9 adalah faktor konversi, dan FP adalah faktor pengenceran.

\section{Analisis Kadar Amilosa dan Amilopektin}

Analisis kadar amilosa dan amilopektin yang dilakukan mengacu pada metode Sompong dkk. (2011) yang dimodifikasi. Kurva standar dibuat dengan menggunakan standar amilosa. Sebanyak $40 \mathrm{mg}$ standar amilosa ditambahkan dengan $1 \mathrm{~mL}$ etanol $96 \%$ dan 9 $\mathrm{mL} \mathrm{NaOH} 1 \mathrm{~N}$, kemudian dipanaskan dalam waterbath selama 10 menit. Larutan standar tersebut kemudian diencerkan menjadi beberapa konsentrasi. Sampel sebanyak $100 \mathrm{mg}$ ditambahkan $1 \mathrm{~mL}$ etanol $96 \%$ dan $\mathrm{NaOH} 1 \mathrm{~N}$ sebanyak $9 \mathrm{~mL}$, kemudian dipanaskan dalam waterbath selama 10 menit. Masing-masing larutan standar dan sampel sebanyak $0,5 \mathrm{~mL}$ ditambahkan dengan $8,75 \mathrm{~mL}$ akuades, $0,5 \mathrm{~mL}$ asam asetat $1 \mathrm{~N}$, dan 0,25 ml larutan I-KI 2\%, kemudian didiamkan selama 30 menit. Selanjutnya dilakukan pengukuran absorbansi larutan standar dan sampel menggunakan spektrofotometer UV-Vis pada panjang gelombang 625 $\mathrm{mn}$. Kadar amilosa diperoleh dengan menggunakan Persamaan 4.

Kadar amilosa $(\%)=\frac{\mathrm{C} \times \mathrm{V} \times \mathrm{F}}{\mathrm{W}} \times 100 \%$

$C$ adalah konsentrasi amilosa contoh dari kurva standar $(\mathrm{mg} / \mathrm{mL}), \mathrm{V}$ adalah volume akhir contoh $(\mathrm{mL}), \mathrm{F}$ adalah faktor pengenceran, dan $\mathrm{W}$ adalah berat contoh $(\mathrm{mg})$. Kadar amilopektin diperoleh berdasarkan selisih kadar pati dengan kadar amilosa sampel.

\section{Analisis Profil Pasting}

Analisis profil pasting dilakukan dengan menggunakan instrumen Rapid Visco Analyzer (RVA) dengan metode yang mengacu pada Widyasaputra (2018). Berat sampel dan air yang digunakan disesuaikan dengan kadar air sampel (berdasarkan hasil rekomendasi instrumen). Sampel dan air dimasukkan ke dalam canester dan dimasukkan ke dalam RVA. Analisis terdiri dari 2 fase, yaitu fase pemanasan dan pendinginan. Pada fase pemanasan, suspensi sampel dipanaskan pada suhu $50{ }^{\circ} \mathrm{C}$ hingga $95{ }^{\circ} \mathrm{C}$ pada kecepatan $6{ }^{\circ} \mathrm{C} /$ menit, yang dipertahankan selama 5 menit. Selanjutnya pada fase pendinginan terjadi penurunan suhu dari $95{ }^{\circ} \mathrm{C}$ menjadi $50{ }^{\circ} \mathrm{C}$ pada kecepatan $6{ }^{\circ} \mathrm{C} /$ menit, yang dipertahankan selama 2 menit. Hasil analisis dinyatakan dalam bentuk plot antara viskositas (CP) dengan perubahan suhu selama fase pemanasan dan pendinginan.

\section{Analisis Solubility dan Swelling Power}

Analisis solubility dan swelling power dilakukan dengan menggunakan metode yang mengacu pada Wang dkk. (2015) dengan modifikasi. Sampel tepung beras hitam sebanyak $0,25 \mathrm{~g}$ dimasukkan ke dalam tabung sentrifus, kemudian ditambahkan akuades sebanyak $10 \mathrm{~mL}$. Sampel dipanaskan di dalam waterbath pada suhu $85^{\circ} \mathrm{C}$ selama 30 menit, dan setiap 10 menit dikocok. Sampel kemudian didinginkan hingga mencapai suhu ruang, kemudian dilakukan sentrifugasi pada kecepatan 3000 rpm selama 30 menit. Supernatan yang diperoleh dipindahkan ke dalam cawan dan dipanaskan pada suhu $105{ }^{\circ} \mathrm{C}$ hingga diperoleh berat konstan untuk mengetahui jumlah pati yang terlarut. Solubility dan swelling power dihitung dengan menggunalan Persamaan 5 dan 6.

$$
\begin{aligned}
& \text { Solubility }=\frac{\text { berat kering supernatan }}{\text { berat kering sampel }} \times 100 \% \\
& \text { Swelling power }=\frac{\text { berat gel }}{\text { berat sampel kering } \times(100-\text { solubility })} \times 100 \%
\end{aligned}
$$

\section{Analisis Statistik}

Analisis dilakukan dengan 2 kali ulangan. Data yang diperoleh dianalisis dengan menggunakan one way ANOVA (analysis of variance), yang dilanjutkan dengan uji Duncan pada taraf $5 \%$ apabila terdapat perbedaan yang signifikan. Analisis data dilakukan dengan menggunakan program XLSTAT 2014.

\section{HASIL DAN PEMBAHASAN}

\section{Total Senyawa Fenolik dan Antosianin}

Hasil analisis total senyawa fenolik untuk masingmasing sampel beras hitam dapat dilihat pada Tabel 1. Data yang diperoleh menunjukkan bahwa terdapat 
perbedaan total senyawa fenolik yang signifikan, terkecuali pada beras hitam Cianjur dengan Galur dan Gadog. Beras hitam yang diuji memiliki total senyawa fenolik yang berkisar antara 261,70 hingga $352,96 \mathrm{mg}$ GAE/100 g. Total senyawa fenolik tertinggi ditemukan pada beras hitam varietas Cempo Ireng, sedangkan yang terendah ditemukan pada varietas Galur. Pedro dkk., (2016) juga melaporkan kandungan senyawa fenolik pada beras hitam yang berasal dari Brasil berkisar antara 339,68 hingga 540,64 mg GAE/100 g.

Tabel 1. Kadar total senyawa fenolik dan antosianin beras hitam

\begin{tabular}{ccc}
\hline Beras hitam & $\begin{array}{c}\text { Total fenolik } \\
\text { (mg GAE/100 g bk } \\
\text { sampel) }\end{array}$ & $\begin{array}{c}\text { Kadar antosianin } \\
\text { (mg/100 g bk } \\
\text { sampel) }\end{array}$ \\
\hline Cianjur & $275,58 \pm 9,17^{\mathrm{bc}}$ & $126,08 \pm 5,48^{\mathrm{a}}$ \\
Cempo Ireng & $352,96 \pm 0,87^{\mathrm{a}}$ & $94,44 \pm 1,91^{\mathrm{c}}$ \\
Galur & $261,70 \pm 5,49^{\mathrm{c}}$ & $52,38 \pm 1,03^{\mathrm{d}}$ \\
Gadog & $280,80 \pm 3,21^{\mathrm{b}}$ & $112,95 \pm 2,25^{\mathrm{b}}$ \\
\hline
\end{tabular}

Keterangan: Nilai pada kolom yang sama diikuti oleh huruf superskrip yang sama menunjukkan tidak berbeda nyata berdasarkan uji Duncan $(p<0,05)$

Komponen fenolik pada beras dapat ditemukan dalam 3 bentuk, yaitu bentuk larut-bebas, larutterkonjugasi, dan terikat (tidak larut). Proporsi komponen fenolik tersebut bergantung pada genotipe dan warna perikarpnya, yaitu pada beras hitam sekitar $81 \%$ dari total polifenolnya berada dalam bentuk terikat (Shao dkk., 2018; Walter dkk., 2013). Menurut Sompong dkk. (2011), pengukuran total senyawa fenolik dengan menggunakan metode FolinCiocalteu tidak dapat menggambarkan jumlah phenolic acids yang ada di dalam sampel secara keseluruhan, sehingga kemungkinan komponen fenolik yang terukur pada penelitian ini adalah komponen fenolik dalam bentuk bebasnya. Oleh sebab itu, tahapan ekstraksi lanjutan dengan $\mathrm{NaOH}$ perlu dilakukan untuk melepaskan komponen fenolik lainnya yang berada dalam bentuk terikat. Komponen fenolik pada beras hitam erat kaitannya dengan aktivitas antioksidan, yang ditunjukkan oleh beberapa hasil penelitian yang menyatakan bahwa terdapat korelasi positif antara kadar total senyawa fenolik terlarut (fraksi bebas) dengan aktivitas antioksidannya (Zhang dkk., 2015).

Antosianin merupakan salah satu komponen antioksidan yang terdapat pada beras hitam (Pang dkk., 2018). Kadar antosianin beras hitam yang dianalisis berkisar antara 52,4 hingga 126,1 mg/100 g (Tabel 1). Beras hitam Cianjur memiliki kadar antosianin tertinggi sedangkan beras hitam Galur selain memiliki kadar total fenolik terendah juga memiliki kadar antosianin terendah. Sompong dkk. (2011) melaporkan bahwa beras hitam yang berasal dari Thailand memiiki kadar antosianin yang berkisar antara 109,5 hingga 256,6 mg/100 g, sedangkan beras hitam yang berasal dari Cina memiliki kandungan antosianin sebesar $244,83 \mathrm{mg} / 100 \mathrm{~g}$. Berdasarkan hal tersebut, hasil kadar antosianin sampel beras hitam pada penelitian ini tidak terlalu jauh berbeda dengan hasil-hasil penelitian sebelumnya, kecuali untuk kadar antosianin beras hitam varietas Galur.

Kadar antosianin yang diperoleh dengan menggunakan metode $\mathrm{pH}$-diferensial merupakan kadar antosianin yang dinyatakan dalam bentuk sianidin3-glukosida ekuivalen. Komponen antosianin utama yang terdapat pada beras hitam adalah dalam bentuk sianidin-3-glukosida dan peonidin-3-glukosida, dengan $>99,5 \%$ dari total antosianin tersebut berada dalam bentuk bebas yang terakumulasi pada lapisan luar (Chen dkk., 2012; Pang dkk., 2018; Walter dkk., 2013; Zhang dkk., 2010). Proporsi senyawa antosianin dalam bentuk sianidin-3-glukosida pada beras hitam lebih tinggi dibandingkan dengan bentuk peonidin-3-glukosida, yaitu berkisar antara 19,4 hingga 140,8 mg/100 g untuk sianidin-3-glukosida, sedangkan dalam bentuk peonidin-3-glukosida berkisar antara 11,1 hingga 12,8 $\mathrm{mg} / 100 \mathrm{~g}$ (Sompong dkk., 2011). Berdasarkan hasil yang diperoleh pada penelitian ini, terlihat bahwa beras hitam yang diuji memilki kandungan senyawa bioaktif yang tinggi, sehingga berpotensi untuk dikembangan sebagai produk pangan fungsional.

\section{Kadar Pati, Amilosa, dan Amilopektin}

Terdapat perbedaan kadar pati yang signifikan antara beras hitam Cianjur, Cempo Ireng dan Galur serta Gadog (Tabel 2). Kadar pati beras hitam yang diperoleh berkisar antara 69,8 hingga 72,7\%. Beras hitam dengan kadar pati tertinggi adalah beras hitam Cianjur, sedangkan yang terendah adalah varietas Gadog. Beras hitam yang digunakan pada penelitian ini memiliki kadar pati yang tidak jauh berbeda dengan beras putih pada penelitian Imanningsih (2012), yang memiliki kadar pati sebesar $67,68 \%$.

Hasil analisis pada Tabel 2 juga menunjukkan bahwa terdapat perbedaan yang signifikan pada kadar amilosa beras hitam yang diuji, namun untuk kadar amilopektin perbedaan yang signifikan hanya ditemukan pada beras Cianjur dan Cempo Ireng dengan beras Galur dan Gadog. Adanya perbedaan yang signifikan pada kadar amilosa dan amilopektin dapat disebabkan oleh perbedaan varietas (sumber pati) dan dapat dipengaruhi pula oleh kondisi iklim dan tanah di tempat penanaman masing-masing beras (Kong dkk., 2015). Kadar amilosa beras hitam yang diperoleh berkisar antara 24,7 hingga 
Tabel 2. Kadar pati beras hitam

\begin{tabular}{|c|c|c|c|}
\hline $\begin{array}{l}\text { Beras } \\
\text { hitam }\end{array}$ & $\begin{array}{l}\text { Kadar pati } \\
\text { (\% bk) }\end{array}$ & $\begin{array}{l}\text { Kadar amilosa } \\
\quad(\% \text { bk })\end{array}$ & $\begin{array}{c}\text { Kadar } \\
\text { amilopektin } \\
(\% \text { bk })\end{array}$ \\
\hline Cianjur & $72,75 \pm 0,64^{a}$ & $25,14 \pm 0,08^{b}$ & $47,61 \pm 0,73^{a}$ \\
\hline $\begin{array}{c}\text { Cempo } \\
\text { Ireng }\end{array}$ & $71,04 \pm 0,06^{b}$ & $22,37 \pm 0,08^{d}$ & $48,66 \pm 0,14^{a}$ \\
\hline Galur & $71,36 \pm 0,59^{b}$ & $26,07 \pm 0,01^{a}$ & $45,30 \pm 0,60^{b}$ \\
\hline Gadog & $69,78 \pm 0,07 c$ & $24,73 \pm 0,18^{c}$ & $45,44 \pm 0,25^{b}$ \\
\hline
\end{tabular}

Keterangan: Nilai pada kolom yang sama diikuti oleh huruf superskrip yang sama menunjukkan tidak berbeda nyata berdasarkan uji Duncan $(p<0,05)$.

$26,1 \%$, sedangkan kadar amilopektinnya berkisar antara 45,3 hingga $48,7 \%$. Beras hitam varietas Galur memiliki kadar amilosa yang tertinggi $(26,07 \%)$ dengan kadar amilopektin yang paling rendah $(45,30 \%)$, sedangkan beras hitam varietas Cempo Ireng memiliki kadar amilosa paling rendah (22,37\%) dengan kadar amilopektinnya yang paling tinggi (48,66\%). Berdasarkan hasil penelitian Sompong dkk. (2011), beras hitam memiliki kadar amilosa berkisar antara 8,9 hingga 25,5\%. Hal ini menunjukkan bahwa kadar amilosa beras hitam yang diuji pada penelitian ini tidak berbeda jauh dengan kadar amilosa beras hitam pada penelitian sebelumnya.

Rasio amilosa-amilopektin pada beras menjadi penting karena dapat mempengaruhi karakteristiknya, salah satunya adalah karakteristik retrogradasinya. Komponen amilosa lebih mudah mengalami retrogradasi dibandingkan dengan amilopektin karena strukturnya yang linear (Kong dkk., 2015). Berdasarkan hal tersebut, maka beras Galur kemungkinan akan memiliki laju retrogradasi yang lebih tinggi atau lebih mudah mengalami retrogradasi dibandingkan dengan ketiga beras lainnya. Hal ini menjadi penting dalam proses pengolahan pangan yang memanfaatkan proses retrogradasi untuk membentuk karakteristik produknya seperti produk-produk mi (Ahmed dkk., 2016).

Berdasarkan kadar amilosanya, beras dapat dikategorikan menjadi beberapa kelompok, yaitu beras tinggi amilosa (25-33\%), beras dengan kadar amilosa sedang (20-25\%), beras rendah amilosa (12-20\%), beras dengan kadar amilosa sangat rendah (2-12\%), dan waxy (1-2\%). Selain itu, beras dengan kadar amilosa $>22 \%$ pada umumnya dapat digunakan dalam pembuatan mi beras (Ahmed dkk., 2016). Jika dilihat dari hasil yang diperoleh, maka beras hitam varietas Galur dan Cianjur termasuk ke dalam kelompok beras amilosa tinggi, sedangkan beras hitam Cempo Ireng dan Gadog termasuk ke dalam kelompok beras amilosa sedang. Selain itu, berdasarkan teori tersebut maka keempat beras yang diuji pada penelitian ini dapat digunakan dalam pembuatan mi.

Kadar amilosa pada beras berkaitan dengan karakteristik cooking dan eating quality. Beras dengan kadar amilosa sedang lebih banyak dipilih dibandingkan dengan beras rendah amilosa ataupun tinggi karena pulen setelah dimasak dan tetap lembut setelah dingin. Beras dengan kadar amilosa rendah akan lengket setelah pemasakan, sedangkan beras tinggi amilosa akan pera dan kering setelah dimasak serta mengeras setelah dingin akibat proses retrogradasi (Sompong dkk., 2011; Syafutri dkk., 2016). Berdasarkan hal tersebut, maka beras hitam Cempo Ireng dan Gadog yang memiliki kadar amilosa sedang akan lebih banyak dipilih untuk dikonsumsi dalam bentuk nasi dibandingkan dengan beras Galur dan Cianjur yang memiliki kadar amilosa tinggi.

\section{Profil Pasting}

Profil pasting masing-masing beras hitam dapat dilihat pada Tabel 3. Berdasarkan parameter peak viscosity, beras hitam Cempo Ireng memiliki nilai yang paling tinggi, sedangkan beras Gadog memiliki nilai yang paling rendah. Peak viscosity menunjukkan viskositas maksimal yang dapat dicapai pati tergelatinisasi selama pemanasan dalam air, yang menunjukkan kapasitas pembengkakan granula pati atau kemampuan pati dalam mengikat air dan sering berkorelasi dengan kualitas akhir produk karena granula yang bengkak dan rusak berkaitan juga dengan tekstur pati yang dimasak (Thomas dkk., 2014; Wani dkk., 2012). Nilai peak viscosity dapat dikaitkan dengan kadar amilosanya, yaitu semakin tinggi kadar amilosa maka nilainya akan semakin rendah karena dengan semakin tingginya kadar amilosa maka pembengkakan granula semakin berkurang akibat amilosa yang menghambat proses pembengkakan granula tersebut (Kim dkk., 2013). Hal ini terlihat dari nilai peak viscosity tertinggi yang dimiliki beras Cempo Ireng (3011 cP) dengan kadar amilosa yang paling rendah jika dibandingkan dengan beras lainnya. Pengecualian terjadi pada beras Cianjur dan Galur, yaitu beras Galur memiliki peak viscosity yang lebih tinggi (2778 cP) dibandingkan dengan beras Cianjur yang memiliki kadar amilosa lebih rendah dan amilopektin lebih tinggi (2531 cP). Kapasitas pembengkakan granula tidak hanya dipengaruhi oleh kadar amilosa dan amilopektin, namun dipengaruhi pula oleh struktur keduanya dan komponen non-karbohidrat yang dapat menghambat pembengkakan granula (Yadav dkk., 2011). Hal inilah yang mungkin dapat menjelaskan hasil yang diperoleh pada penelitian ini. Berdasarkan hasil yang diperoleh, maka beras Cempo Ireng memiliki kapasitas pembengkakan granula atau pengikatan air 
yang paling tinggi jika dibandingkan dengan ketiga beras lainnya.

Beras hitam Cianjur memiliki nilai viskositas breakdown yang paling rendah (934 cP), sedangkan beras Cempo Ireng memiliki nilai yang tertinggi (1784 cP) (Tabel 3). Viskositas breakdown dapat dikaitkan dengan kadar amilosa, yaitu semakin tinggi kadar amilosa maka viskositas breakdown akan semakin rendah akibat terbatasnya pembengkakan granula pada pati dengan amilosa tinggi (Kim dkk., 2013). Hal ini terlihat pada beras hitam Cempo Ireng yang memiliki kadar amilosa paling rendah dan memiliki viskositas breakdown yang tertinggi (1784 cP) jika dibandingkan dengan beras lainnya. Viskositas breakdown menunjukkan ketahanan pasta pati terhadap panas dan shearing process (Kong dkk., 2015). Berdasarkan hal tersebut, maka beras hitam Cianjur memiliki ketahanan terhadap suhu tinggi dan shearing process yang lebih baik dibandingkan dengan beras hitam lainnya, sehingga cocok untuk digunakan dalam proses pengolahan yang melibatkan suhu tinggi dan shearing process seperti ekstrusi. Pati yang memiliki ketahanan terhadap suhu tinggi dan shearing process
Final viscosity sering digunakan sebagai parameter kualitas untuk mengukur kekuataan gel yang terbentuk setelah proses pendinginan (Thomas dkk., 2014). Berdasarkan hal tersebut, maka beras hitam Cianjur, Cempo Ireng, dan Galur memiliki kekuatan gel yang lebih besar dibandingkan dengan beras hitam Gadog.

Beras Cempo Ireng dan Galur memiliki viskositas setback yang tidak berbeda secara signifikan, namun berbeda signifikan dengan beras Cianjur dan Gadog, yaitu memiliki nilai yang lebih tinggi (Tabel 3). Viskositas setback berkaitan dengan retrogradasi dan konsistensi gel yang terbentuk oleh molekul pati, yang juga merupakan ukuran proses kristalisasi kembali pati yang sudah tergelatinisasi selama proses pendinginan (Thomas dkk., 2014). Viskositas setback juga berkaitan dengan kadar amilosa, yaitu semakin tinggi kadar amilosa maka nilai viskositas setback akan semakin tinggi (Kim dkk., 2013). Komponen amilosa lebih mudah mengalami retrogradasi dibandingkan dengan amilopektin karena strukturnya yang linear, sehingga lebih mudah untuk membentuk ikatan hidrogen antar molekulnya, yang dapat berperan dalam pembentukan

Tabel 3. Profil pasting beras hitam

\begin{tabular}{lcccc}
\hline \multirow{2}{*}{ Parameter } & \multicolumn{4}{c}{ Beras hitam } \\
\cline { 2 - 5 } & Cianjur & Cempo Ireng & Galur & Gadog \\
\hline Peak viscosity (cP) & $2531 \pm 24,04^{\mathrm{c}}$ & $3011 \pm 70,00^{\mathrm{a}}$ & $2778 \pm 10,61^{\mathrm{b}}$ & $2214 \pm 28,28^{\mathrm{d}}$ \\
Breakdown viscosity (cP) & $934 \pm 11,31^{\mathrm{d}}$ & $1784 \pm 55,15^{\mathrm{a}}$ & $1489 \pm 28,28^{\mathrm{b}}$ & $1092 \pm 45,25^{\mathrm{c}}$ \\
Final viscosity (cP) & $4105 \pm 47,38^{\mathrm{a}}$ & $4080 \pm 45,96^{\mathrm{a}}$ & $4175 \pm 17,68^{\mathrm{a}}$ & $3732 \pm 16,97^{\mathrm{b}}$ \\
Setback viscosity (cP) & $2508 \pm 34,65^{\mathrm{c}}$ & $2853 \pm 31,11^{\mathrm{a}}$ & $2886 \pm 28,28^{\mathrm{a}}$ & $2610 \pm 7,78^{\mathrm{b}}$ \\
Peak time (min) & $9,7 \pm 0,00^{\mathrm{a}}$ & $9,3 \pm 0,04^{\mathrm{b}}$ & $9,1 \pm 0,04^{\mathrm{c}}$ & $9,1 \pm 0,04^{\mathrm{c}}$ \\
Pasting temperature $\left({ }^{\circ} \mathrm{C}\right)$ & $88,8 \pm 0,25^{\mathrm{a}}$ & $78,3 \pm 0,32^{\mathrm{c}}$ & $76,7 \pm 0,25^{\mathrm{d}}$ & $87,8 \pm 0,00^{\mathrm{b}}$ \\
\hline
\end{tabular}

Keterangan: Nilai pada baris yang sama diikuti oleh huruf superskrip yang sama menunjukkan tidak berbeda nyata berdasarkan uji Duncan $(p<0,05)$.

seringkali dijadikan sebagai faktor penting dalam beberapa proses pengolahan di industri pangan, sehingga parameter viskositas breakdown seringkali dijadikan sebagai salah satu parameter penentu dalam penggunaan pati di industri pangan (Sompong dkk., 2011).

Data pada Tabel 3 juga menunjukkan bahwa beras hitam Cianjur, Cempo Ireng, dan Galur memiliki nilai final viscosity yang tidak berbeda secara signifikan, namun ketiganya memiliki perbedaan yang signifikan jika dibandingkan dengan beras Gadog dan memiliki nilai yang lebih tinggi. Final viscosity merupakan parameter yang menunjukkan proses penyusunan kembali molekul pati ketika didinginkan, yang menyebabkan terbentuknya gel sehingga viskositasnya meningkat. gel yang kuat (Kong dkk., 2015). Hal ini terlihat pada hasil yang diperoleh, yaitu beras Galur yang memiliki kadar amilosa yang paling tinggi juga memiliki nilai viskositas setback yang paling tinggi. Viskositas setback juga merupakan indikator tekstur produk akhir dan berkaitan dengan sineresis selama siklus freeze-thaw (Wani dkk., 2012).

Peak time merupakan waktu pada saat viskositas mencapai nilai maksimum selama proses pemanasan pada RVA (Kong dkk., 2015). Beras hitam Cianjur dan Cempo Ireng memiliki nilai peak time yang berbeda signifikan dengan beras Galur dan Gadog, dengan nilai yang paling tinggi dimiliki oleh beras Cianjur (Tabel 3). Pasting temperature merupakan suhu pada saat pati mulai mengalami kenaikan viskositas selama 
pemanasan (Wani dkk., 2012). Beras Cianjur memiliki pasting temperature yang paling tinggi dibandingkan dengan beras lainnya, sedangkan beras hitam Galur memiliki nilai yang paling rendah (Tabel 3 ). Hal ini menunjukkan bahwa beras Galur akan mengalami kenaikan viskositas pada suhu yang lebih rendah dan akan lebih cepat mencapai viskositas maksimumnya dibandingkan dengan beras hitam lainnya, sedangkan beras Cianjur akan mengalami kenaikan viskositas pada suhu yang lebih tinggi dan waktu yang lebih lama dibandingkan dengan beras lainnya.

\section{Solubility dan Swelling Power}

Nilai solubility dan swelling power masing-masing beras hitam dapat dilihat pada Tabel 4. Beras Gadog memiliki nilai solubility yang paling tinggi dibandingkan dengan sampel lainnya (8,42\%), sedangkan beras Galur memiliki nilai yang paling rendah (6,39\%). Solubility atau kelarutan merupakan hasil dari leaching amilosa selama pembengkakan granula dan juga mengindikasikan derajat dispersi granula pati dalam air selama pemanasan, sehingga semakin tinggi kelarutannya maka semakin banyak amilosa yang keluar dari granula pati (Wu dkk., 2015). Solubility dipengaruhi oleh kadar amilosanya karena amilosa berperan dalam mempertahankan struktur granula pati, yaitu semakin tinggi jumlahnya maka granula akan semakin kompak dan amilosa akan semakin sulit untuk meluap keluar dari granula yang ditunjukkan dengan nilai solubility yang rendah (Xie dkk., 2017). Hasil yang diperoleh pada penelitian ini sejalan dengan teori tersebut, yaitu beras dengan kadar amilosa tertinggi (beras Galur) memiliki nilai solubility yang paling rendah dibandingkan dengan beras lainnya.

Tabel 4. Solubility dan swelling power beras hitam

\begin{tabular}{ccc}
\hline Beras hitam & Solubility (\% bk) & $\begin{array}{c}\text { Swelling power } \\
(\% \mathrm{bk})\end{array}$ \\
\hline Cianjur & $8,02 \pm 0,18^{\mathrm{b}}$ & $6,33 \pm 0,02^{\mathrm{c}}$ \\
Cempo Ireng & $8,21 \pm 0,19^{\mathrm{ab}}$ & $7,28 \pm 0,02^{\mathrm{a}}$ \\
Galur & $6,39 \pm 0,03^{\mathrm{c}}$ & $6,95 \pm 0,41^{\mathrm{ab}}$ \\
Gadog & $8,42 \pm 0,03^{\mathrm{a}}$ & $6,55 \pm 0,01^{\mathrm{bc}}$ \\
\hline
\end{tabular}

Keterangan: Nilai pada kolom yang sama diikuti oleh huruf superskrip yang sama menunjukkan tidak berbeda nyata berdasarkan uji Duncan $(p<0,05)$

Beras hitam Cempo Ireng memiliki nilai swelling power yang tertinggi $(7,28 \%)$, sedangkan beras Cianjur memiliki nilai yang terendah $(6,33 \%)$ (Tabel 4). Kapasitas pembengkakan granula secara langsung berkaitan dengan kadar amilopektin karena amilosa yang berperan sebagai penghambat pembengkakan, yaitu semakin tinggi proporsi amilopektin rantai pendek maka swelling power akan meningkat (Alcázar-Alay dan Meireles, 2015; Wu dkk., 2015). Teori tersebut berlaku pada beras Cempo Ireng yang memiliki kadar amilosa terendah dan amilopektin tertinggi (22,37\% dan $48,66 \%)$, yang ditunjukkan dengan nilai swelling power yang tertinggi dibandingkan dengan ketiga beras lainnya. Hal yang berbeda terjadi pada beras Galur dengan kadar amilosa tertinggi dan amilopektin terendah $(26,07 \%$ dan $45,30 \%)$, yaitu memiliki swelling power lebih tinggi $(6,95 \%)$ jika dibandingkan dengan beras Cianjur yang memiliki kadar amilosa lebih rendah dan amilopektin lebih tinggi $(25,14 \%$ dan $47,61 \%)$. Swelling power tidak hanya dipengaruhi oleh proporsi amilosa-amilopektin, namun berkaitan pula dengan struktur amilosa dan amilopektin, serta adanya komponen non-karbohidrat seperti lipid yang berperan sebagai inhibitor pembengkakan (Yadav dkk., 2011). Hal inilah yang mungkin dapat menjelaskan hasil yang diperoleh tersebut. Pati yang terbatas pembengkakan granulanya akan lebih tahan terhadap shearing selama pemasakan, sehingga cocok untuk digunakan dalam pembuatan produk-produk mi (Wu dkk., 2015). Jika dilihat dari hasil yang diperoleh, maka beras Cianjur dan Gadog kemungkinan akan cocok digunakan dalam pembuatan mi karena memiliki swelling power yang rendah.

\section{KESIMPULAN}

Masing-masing beras hitam yang digunakan pada penelitian ini memiliki karakteristik yang berbedabeda. Keempat beras hitam yang dianalisis berpotensi menjadi sumber pangan fungsional karena kandungan komponen bioaktifnya (total fenolik dan antosianin) yang tinggi. Analisis karakteristik fisikokimia beras hitam yang dilakukan dapat membantu untuk menentukan bagaimana penggunaan beras hitam dalam proses pengolahan. Kadar pati, proporsi amilosa-amilopektin pada beras hitam menjadi salah satu faktor penting karena mempengaruhi karakteristik selama pemasakan dan produk akhir. Berdasarkan karakteristik profil pasting, solubility dan swelling power dapat diketahui sifat ketahanan pati beras terhadap proses pemanasan dan karakteristiknya setelah proses pendinginan, sehingga dapat diketahui bentuk pemanfaatan beras yang tepat pada pengolahan pangan. Berdasarkan kadar amilosanya, keempat beras hitam yang dianalisis dapat digunakan dalam pembuatan mi, namun beras Cianjur dinilai akan lebih cocok jika dilihat dari karakteristik profil pasting dan swelling power yang dimilikinya. Beras hitam Cempo Ireng dan Gadog akan lebih dipilih untuk dikonsumsi dalam bentuk nasi karena mengandung kadar amilosa sedang. 
Penelitian lebih lanjut mengenai sifat fungsional beras hitam asal Jawa Barat ini penting untuk dilakukan, mengingat data yang diperoleh pada penelitian ini menunjukkan bahwa beras hitam tersebut memiliki kandungan senyawa bioaktif yang tinggi, yaitu analisis aktivitas antioksidan yang dapat dikaitkan pula dengan kandungan senyawa bioaktifnya untuk memperkuat potensi beras hitam yang diteliti sebagai sumber pangan fungsional. Selain itu, sebagai tambahan informasi dapat juga dilakukan analisis senyawa fenolik berdasarkan fraksinya (bebas-larut, bebas-terkonjugasi, dan terikat) untuk mengetahui proporsi masing-masing fraksi, analisis profil senyawa fenolik dan antosianin menggunakan HPLC untuk melihat komposisinya, serta analisis sifat fisik seperti analisis warna untuk melihat hubungan antara warna beras hitam dengan kandungan senyawa bioaktif yang dimiliki. Dengan informasi yang diperoleh, tentunya diharapkan dapat memberikan kontribusi baik dalam pengembangan keilmuan, maupun dalam pengembangan produk-produk pangan fungsional.

\section{KONFLIK KEPENTINGAN}

Penulis menyatakan bahwa tidak ada konflik kepentingan dari berbagai pihak pada penelitian ini.

\section{DAFTAR PUSTAKA}

Ahmed, I., Qazi, I. M., Li, Z., \& Ullah, J. (2016). Rice noodles: Materials, processing and quality evaluation. Proceedings of the Pakistan Academy of Sciences: Part B, 53(3B), 215-238.

Alcázar-Alay, S. C., \& Meireles, M. A. A. (2015). Physicochemical properties, modifications and applications of starches from different botanical sources. Food Science and Technology, 35(2), 215-236. https://doi.org/10.1590/1678-457X.6749

Chen, X. Q., Nagao, N., Itani, T., \& Irifune, K. (2012). Antioxidative analysis, and identification and quantification of anthocyanin pigments in different coloured rice. Food Chemistry, 135(4), 2783-2788. https://doi.org/10.1016/j. foodchem.2012.06.098

Imanningsih, N. (2012). Profil Gelatinisasi Beberapa Formulasi Tepung-Tepungan Untuk Pendugaan Sifat Pemasakan. Penel Gizi Makan, 35(1), 13-22. Retrieved from https:// media.neliti.com/media/publications/223473-profilgelatinisasi-beberapa-formulasi-t.pdf

Kang, M. Y., Kim, J. H., Rico, C. W., \& Nam, S. H. (2011). A comparative study on the physicochemical characteristics of black rice varieties. International Journal of Food Properties, 14(6), 1241-1254. https://doi. org/10.1080/10942911003637350
Kang, Y. J., Jung, S. W., \& Lee, S. J. (2014). An optimal extraction solvent and purification adsorbent to produce anthocyanins from black rice (Oryza sativa cv. Heugjinjubyeo). Food Science and Biotechnology, 23(1), 97-106. https://doi.org/10.1007/s10068-014-0013-8

Kim, H. S., Patel, B., \& Bemiller, J. N. (2013). Effects of the amylose-amylopectin ratio on starch-hydrocolloid interactions. Carbohydrate Polymers, 98(2), 1438-1448. https://doi.org/10.1016/j.carbpol.2013.07.035

Kong, S., Kim, D. J., Oh, S. K., Choi, I. S., Jeong, H. S., \& Lee, J. (2012). Black Rice Bran as an Ingredient in Noodles: Chemical and Functional Evaluation. Journal of Food Science, 77(3). https://doi.org/10.1111/j.17503841.2011.02590.x

Kong, X., Zhu, P., Sui, Z., \& Bao, J. (2015). Physicochemical properties of starches from diverse rice cultivars varying in apparent amylose content and gelatinisation temperature combinations. Food Chemistry, 172, 433-440. https:// doi.org/10.1016/j.foodchem.2014.09.085

Kushwaha, U. K. S. (2016). Black Rice: Research, History and Development. Switzerland: Springer International Publishing Switzerland.

Nurhidajah, Ulvie, Y. N. S., \& Suyanto, A. (2018). Karakteristik Fisik Dan Kimia Beras Hitam Dengan Variasi Metode Pengolahan. Prosiding Seminar Nasional Unimus, 1, 216-221. Semarang, Indonesia.

Pang, Y., Ahmed, S., Xu, Y., Beta, T., Zhu, Z., Shao, Y., \& Bao, J. (2018). Bound phenolic compounds and antioxidant properties of whole grain and bran of white, red and black rice. Food Chemistry, 240(January 2017), 212-221. https://doi. org/10.1016/j.foodchem.2017.07.095

Pedro, A. C., Granato, D., \& Rosso, N. D. (2016). Extraction of anthocyanins and polyphenols from black rice (Oryza sativa L.) by modeling and assessing their reversibility and stability. Food Chemistry, 191, 12-20. https://doi.org/10.1016/j. foodchem.2015.02.045

Pengkumsri, N., Chaiyasut, C., Saenjum, C., Sirilun, S., Peerajan, S., Suwannalert, P., ... Sivamaruthi, B. S. (2015). Physicochemical and antioxidative properties of black, brown and red rice varieties of northern Thailand. Food Science and Technology, 35(2), 331-338. https://doi.org/10.1590/1678$457 X .6573$

Sani, W., Iswadi, \& Samingan. (2014). Kandungan Pati pada Bonggool Pisang. Prosiding Seminar Nasional Biologi 2014, 2, 187-192.

Shao, Y., Hu, Z., Yu, Y., Mou, R., Zhu, Z., \& Beta, T. (2018). Phenolic acids, anthocyanins, proanthocyanidins, antioxidant activity, minerals and their correlations in non-pigmented, red, and black rice. Food 
Chemistry, 239, 733-741. https://doi.org/10.1016/j. foodchem.2017.07.009

Sompong, R., Siebenhandl-Ehn, S., Linsberger-Martin, G., \& Berghofer, E. (2011). Physicochemical and antioxidative properties of red and black rice varieties from Thailand, China and Sri Lanka. Food Chemistry, 124(1), 132-140. https://doi. org/10.1016/j.foodchem.2010.05.115

Syafutri, M. I., Pratama, F., Syaiful, F., \& Faizal, A. (2016). Effects of Varieties and Cooking Methods on Physical and Chemical Characteristics of Cooked Rice. Rice Science, 23(5), 282-286. https://doi.org/10.1016/j. rsci.2016.08.006

Thomas, R., Bhat, R., Kuang, Y. T., \& Abdullah, W. N. $W$. (2014). Functional and pasting properties of locally grown and imported exotic rice varieties of malaysia. Food Science and Technology Research, 20(2), 469-477. https://doi.org/10.3136/fstr.20.469

Walter, M., Marchesan, E., Massoni, P. F. S., da Silva, L. P., Sartori, G. M. S., \& Ferreira, R. B. (2013). Antioxidant properties of rice grains with light brown, red and black pericarp colors and the effect of processing. Food Research International, 50(2), 698-703. https://doi.org/10.1016/j.foodres.2011.09.002

Wang, D., Fan, D. C., Ding, M., Ge, P. Z., \& Zhou, C. Q. (2015). Characteristics of different types of starch in starch noodles and their effect on eating quality. International Journal of Food Properties, 18(11), 2472-2486. https://doi.org/10.1080/10942912.20 14.983606

Wani, A. A., Singh, P., Shah, M. A., Schweiggert-Weisz, U., Gul, K., \& Wani, I. A. (2012). Rice Starch Diversity: Effects on Structural, Morphological, Thermal, and Physicochemical Properties-A Review.
Comprehensive Reviews in Food Science and Food Safety, 11(5), 417-436. https://doi.org/10.1111/ j.1541-4337.2012.00193.x

Widyasaputra, R. (2018). Optimasi proses produksi beras hitam pratanak dengan metode permukaan respon. Institut Pertanian Bogor.

Wu, F., Meng, Y., Yang, N., Tao, H., \& Xu, X. (2015). Effects of mung bean starch on quality of rice noodles made by direct dry flour extrusion. $L W T$ Food Science and Technology, 63(2), 1199-1205. https://doi.org/10.1016/j.Iwt.2015.04.063

Xie, L. H., Tang, S. Q., Luo, J., Wei, X. J., Shao, G. N., Jiao, G. A., ... Hu, P. S. (2017). Physiochemical properties of rice starch for production of vermicelli with premium quality. Journal of Food Science and Technology, 54(12), 3928-3935. https://doi. org/10.1007/s13197-017-2852-9

Yadav, B. S., Yadav, R. B., \& Kumar, M. (2011). Suitability of pigeon pea and rice starches and their blends for noodle making. LWT - Food Science and Technology, 44(6), 1415-1421. https://doi.org/10.1016/j. Iwt.2011.01.004

Zhang, H., Shao, Y., Bao, J., \& Beta, T. (2015). Phenolic compounds and antioxidant properties of breeding lines between the white and black rice. Food Chemistry, 172, 630-639. https://doi.org/10.1016/j. foodchem.2014.09.118

Zhang, M. W., Zhang, R. F., Zhang, F. X., \& Liu, R. H. (2010). Phenolic profiles and antioxidant activity of black rice bran of different commercially available varieties. Journal of Agricultural and Food Chemistry, 58(13), 7580-7587. https://doi.org/10.1021/ jf1007665 